\title{
IMPACT OF FORMATIVE ASSESSMENT PRACTICES ON STUDENT MOTIVATION FOR LEARNING THE ENGLISH LANGUAGE
}

\section{Anita Muho ${ }^{1+}$ \\ Gentjana Taraj ${ }^{2}$}

\author{
1,2Aleksandër Moisiu University of Durrës, Albania. \\ 'Email:anitamuho@yahoo.itTel: +355692419400 \\ EEmail: gentaraj.uv@gmail.com Tel:+355694875731
}

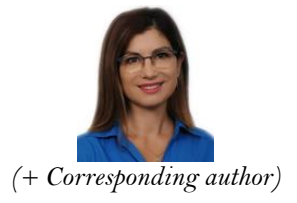

ABSTRACT

\section{Article History \\ Received: 15 September 2021 Revised: 8 December 2021 \\ Accepted: 28 December 2021 Published: 10 January 2022}

\section{Keywords}

Assessment practices English language Formative assessment Motivation for learning.

\begin{abstract}
This study aimed at exploring the impact of formative assessment practices on student motivation for learning the English language. As Leahy, Lyon, Thompson, and Wiliam (2005) stated, education needs to change its function from collecting the results of right or wrong, and to encourage teachers in gathering information that will affect the educational decisions. This study is a non-experimental, correlational study, to describe the relationship between formative assessment practices and motivation for leaning. The instrument used was a questionnaire on high school students from public and private schools, who were selected randomly by stratified sampling. They belonged to three major high schools of Durres, Albania. The findings of this study showed that factors like strategic questions used by the teacher during formative assessment, student's portfolio, self-assessment, and peer assessment affected positively the motivation for learning the English language. The results of the regression equation revealed that from four independent variables, the factor that had the greatest impact on motivation for learning were strategic questions used by the teacher during formative assessment, followed by self-assessment, peer assessment and student's portfolio. This study identified ways of intervention to promote motivation for learning the English language. The study will contribute in the Albanian context showing how assessment practices made an impact on student motivation. It will help educational institutions and policy makers, foreign language teachers in improving the assessment practices to promote student motivation in learning the English language.
\end{abstract}

Contribution/Originality: The paper's primary contribution is studying the impact of formative assessment practices on student motivation and establishing it as a key factor in second language learning. The study noted a few deficiencies in studying the effects of assessment practices on student motivation.

\section{INTRODUCTION}

Foreign language learning is considered a necessity of the current time in all cycles of the education system, especially in the study of international literature and gaining professional and scientific knowledge. Nevertheless, what we see and feel every day in classes, shows a picture of students who have lessened interest in foreign language learning. On the other hand, the ongoing reform of our education system necessitates a kind of assessment of students in schools without bypassing traditional assessment practices in order to encourage and motivate them. In their every day practices, teachers use traditional forms of assessment, but regardless of the method or technique selected, a few questions are included such as: Is student assessment motivational? Are they motivated by classroom assessment and whether they prefer a different assessment practice? 
Traditional school assessment includes a device in providing a learning index, which is based on a predicted model, where: teachers give instruction, test students' knowledge about content, judge their achievements based on "testing" and then continue with the following instruction. This way of assessment is not clear nowadays because societal expectations of education change and cognitive science have produced new results about learning nature. This assumption has already been questioned. Scholars like O’Connor (2009); Reeves (2007) and Marzano (2006) have proposed significant modifications in grading policies to encourage an atmosphere that is more concerned with learning than with grades and classifications. Marzano (2006); O'Connor (2009) and Reeves (2007) are only a few examples. Assessment in the new setting should be tailored to students' requirements, learning styles, and motivation to learn a foreign language.

Another issue of concern is how teachers and students can change their roles to fit into a new assessment culture. To ensure that "the next step" enhances the quality of learning, teachers and students should be willing to change roles to support learning (Black, Harrison, Lee, Marshall, \& Wiliam, 2004). Students should change their role in the assessment, from passive recipients to active ones, who can take the responsibility to manage their learning (Black et al., 2004). With their involvement in assessment, they can assess themselves and others to identify strengths and weaknesses.

The main objective of this study was to identify students' perceptions about formative assessment practices and to determine the relationship between assessment practices and motivation for learning the English language. To achieve the research objective, this study answered the following research questions:

1. How is perceived by the students the use of portfolio as an assessment method in learning English?

2. How is perceived by the students the use of self-assessment as an assessment method in learning English?

3. How is perceived by the students the use of peer-assessment as an assessment method in learning English?

4. How is perceived by the students the use of teachers' strategic questions as an assessment method in learning English?

5. Is there a relationship between assessment practices (Portfolio, self-assessment, peer assessment, and teachers' strategic questions) and motivation for learning English, and which are the assessment practices with greater impact on students' motivation for learning?

Based on these questions, a hypothesis was established:

H: There is a positive relationship between assessment practices (students' portfolio, self-assessment, peer assessment, and teachers' strategic questions) and students' motivation for learning English.

The issue of student assessment in school has been addressed widely in education reforms, but after research conducted in Albania, it is noted that there are deficiencies in the study of the effects of different assessment practices on students' motivation. The impact of assessment on student motivation is very important and a key factor in second language acquisition. We need to understand the assessment practices and their impact on student motivation, to understand and encourage positive motivation through the assessment.

It is hoped that this study will serve to improve assessment practices and promote student motivation in learning a second language, given the fact that there is a positive relationship between motivation and assessment practices (Stefanou, 2003).

\section{LITERATURE REVIEW}

\subsection{Assessment Practices According to their Purpose}

Assessment practices according to their purpose are divided into two major groups: formative and summative assessment. Terms "summative" and "formative" assessment are in usage since 1950. Initially, Benjamin Bloom used these terms in 1960 and later Scriven (1967) used them. Bloom (1969) asserted that when the assessment is in line with teaching and learning process, it will have a positive effect on student achievement and motivation. It aims to 
support learning (formative assessment) and gain certification of achievements (summative assessment) (William \& Thompson, 2008).

The main difference between summative and formative assessment also relates to the information collected. The summative assessment uses information to compare students' performance against each other, or if they have reached the learning targets at the end of the lesson. The formative assessment uses information collected to determine the learning gap and what to do to close it. Looney (2011) also presented a similar distinction when he stated, "Summative assessment can be used for promotion, certification, or admission to higher levels of education. Formative assessment, in contrast, is based on information gathered during the assessment process, to identify learning needs and adapt teaching. Summative assessment is sometimes defined as the assessment of learning and formative assessment as assessment for learning.

Black and Wiliam (2009) have emphasized the fact that the assessment is used to support learning; however, they recognized the importance of using assessment for certification and evaluation. Therefore, the difference between formative and summative assessment lay in the function they performed. If you want to help students improve their learning process by giving them feedback about the points of their strengths and weaknesses, we practice formative assessment, and if we assess students after a chapter, semester, year, or course, we use summative assessment.

Moss and Brookhart (2009) also presented a summary of features of these assessment practices according to their purpose, recommending to face them one by one and at the same time, highlighting the best features of formative assessment as a response to the need for change in assessment practices (See Table 1).

Table 1. Features of assessment practices

\begin{tabular}{l|l}
\hline $\begin{array}{l}\text { Formative Assessment } \\
\text { (Assessment for Learning) }\end{array}$ & $\begin{array}{l}\text { Summative Assessment } \\
\text { (Assessment of Learning) }\end{array}$ \\
\hline Purpose: To improve learning and achievement & $\begin{array}{l}\text { Purpose: Attainment should be measured or } \\
\text { audited. }\end{array}$ \\
\hline $\begin{array}{l}\text { It is done while you are learning day by day, minute by } \\
\text { minute. }\end{array}$ & $\begin{array}{l}\text { Conducted on a regular basis to create } \\
\text { snapshots of what has occurred. }\end{array}$ \\
\hline Emphasis on the learning process and growth. & Emphasis on the outcomes of learning. \\
\hline $\begin{array}{l}\text { Assumed to be an essential component of the teaching- } \\
\text { learning process. }\end{array}$ & $\begin{array}{l}\text { Assumed as a distinct activity, following the } \\
\text { teaching-learning cycle. }\end{array}$ \\
\hline $\begin{array}{l}\text { Collaborative- Teachers and students know where they } \\
\text { are going, they are aware of the learning requirements, } \\
\text { and they use assessment data as feedback to guide and } \\
\text { change their actions to fulfil those requirements. }\end{array}$ & $\begin{array}{l}\text { Teacher directed- Teachers give students } \\
\text { tasks to do and then assess how well they } \\
\text { complete them. }\end{array}$ \\
\hline $\begin{array}{l}\text { Fluid- A continuous process impacted by student } \\
\text { needs and feedback from teachers. }\end{array}$ & $\begin{array}{l}\text { Rigid- A constant indicator of the student's } \\
\text { accomplishments. }\end{array}$ \\
\hline $\begin{array}{l}\text { Intentional learners' role is adopted by both teachers } \\
\text { and students. }\end{array}$ & $\begin{array}{l}\text { Teachers play the part of auditors, while } \\
\text { students play the part of the audited. }\end{array}$ \\
\hline $\begin{array}{l}\text { Teachers and students utilize the data they collect to } \\
\text { make modifications to improve over time. }\end{array}$ & $\begin{array}{l}\text { Teachers use the data to determine if a series } \\
\text { of instructional activities is a "success" or a } \\
\text { failure." }\end{array}$ \\
\hline \begin{tabular}{l} 
Source: Moss and Brookhart(2009). \\
\hline
\end{tabular}
\end{tabular}

According to the above definitions, formative assessment or assessment for learning is to improve teaching, learning, and increase student achievement, while summative assessment or assessment of learning aims to measure student achievement. Formative assessment model is a teaching tool that fosters learning and not a teaching practice designed only to assess and grade, because if the students are involved in the assessment process, they begin to consider it not just as testing, but as a process of learning (Davies, 2008). So, formative assessment keeps 
under control the progress of learning while summative assessment serves as a final assessment of a chapter or curriculum. Summative assessment determines the performance at the end of the chapter or the course to set grades and certification. Summative assessment can also be used to judge the effectiveness of teaching or learning program.

\subsection{Findings of Empirical Studies on the Impact of Assessment Practices on Students' Motivation}

Black and Wiliam (1998b) studied the nature and extent of assessment used in education. Their studies showed that the main beneficiaries of formative assessment were students although they responded to the current educational system focusing on reward, known as "grades.” Students were encouraged to get high grades; avoiding learning due to the fear getting poor grades, rather than generate learning themselves (Black \& Wiliam, 1998b). It was necessary for students to focus on learning and not on grades or seeking compensation.

Black et al. (2004) conducted a research study of 19 middle school teachers and their students in the UK. The research used meta-analysis suggestions of Black and Wiliam (1998b) applied in a school environment, designed to measure student achievement results. Assessment Practices treated in this study were the teachers' questions, feedback associated with grades, self-assessment, peer assessment, and formative use of summative tests. The result of this experiment had a 0.3 standard deviation effect in a variety of achievement tests administered (Black et al., 2004).

Dweck (2001) proved that frequent assessments (based on the grades) had a negative effect on motivation for learning, self-esteem impairs low-achieving pupils by making them feel hopeless. This viewpoint was also supported by the study of Lepper, Greene, and Nisbett (1973) who concluded that students who had previously chosen to include their wishes in an activity and where their satisfaction was evident, had less tendency to turn again to this activity after they were awarded a grade from the teacher for their participation.

Brookhart, Moss, and Long (2009) stated: The influence of assessment practices on students' learning achievement has highlighted the findings of a five-year collaborative study of the Armstrong School, in western Pennsylvania and the Center for Development of Teaching and learning, School of Education, University of Duquesne, in Pittsburgh, Pennsylvania. The study was based on factors like formative assessment, teacher-student communication and students' ownership of the learning process. The study pointed out that formative assessment was closely related to students' intrinsic motivation and helped them to utilize their capacities, establish, and strengthen four important components of motivation for learning:

- Self-efficacy: students' confidence on their ability to succeed in a particular situation.

- Self-regulation: students' role, as active participants in the learning process.

- Self-esteem: students learn to analyze and judge their performance according to criteria and determine how they can improve it.

- Self-attribution: students' perceptions or explanations about success or failure, which determine the amount of effort in the future.

Research studies mentioned above showed that formative assessment practices enabled students to build knowledge, understanding, and achieve their objectives and, at the same time enabled them to think critically and creatively promote self-efficacy, self-regulation, self-esteem, and self-attribute (Stiggins, 2007).

\subsection{Formative Assessment as a Response to Change}

If we refer to etymology of assessment in English, it comes from the Latin assedere, which means to sit beside someone. Theoretically, to sit beside the students to talk, listen, and follow them in their work will provide the best information about their level of learning, on which teachers should base their decisions, but teaching contexts, where many students are not ideal environments for such individual control. In most classrooms, teachers cannot sit beside every student, but they can use the assessment practices, which enables the collection of information they need and, at the same time support decisions about teaching and learning. 
Formative assessment has its roots in theories of Sadler (1983); Sadler (1989) while Scriven (1967) created the term formative assessment to assess programs, creating opportunities to use assessment results to improve programs. Bloom, Hastings, and Madaus (1971) applied the concept of formative assessment in the classroom, focusing on the use of formative assessment by teachers to gather information and to use it in selecting teaching practices and materials. Bloom (1984) found formative assessment practices when he and his students were searching for group-teaching methods, which should be as effective as individual teaching methods. Bloom and his students found that out of learning ownership and teacher-centered formative assessment practices, there was no single approach that improved learning, but after expanding the information taken, it was more beneficial to learning. Later Sadler (1983); Sadler (1989) also accepted the concept of formative assessment in its present form.

Popham (2008) also states that teachers and students can affect to change the teaching process. More specifically, it defines assessment in this way, "Assessment provides information about student achievement, which is used by teachers to improve their teaching practices." In the above definition, we find three main components: evidence of students' knowledge, the nature of feedback given, and improving teaching practices. These three key elements of formative assessment are also distinguished by Brookhart (2011) "Formative assessment involves: 1) collecting information about teaching practices, 2) instructional decisions taken on the basis of information collected, 3) helping students based on their needs to improve."

The Council (2006) also defines formative assessment as "An ongoing process that allows gathering information about strengths and weakness." Therefore, teachers use the information collected to create an overview about the final assessment of students and at the same time, this information is shared with students so that they are aware of the progress made. On the other hand, summative assessment is defined as the process of controlling learning at the end of the lesson by giving grades."

Stiggins (2007) claims that the reason why formative assessment has the effect on students' learning because its philosophy is rooted in changing and improving students and treating them as an active part of assessment. Even Leahy et al. (2005) supported this idea, noting that education needs to change its function from collecting the results of right or wrong, to encourage teachers to gather information that will affect the educational decisions. Despite the rising attention, teachers have only embraced these evaluation methodologies to a limited extent (Boud et al., 2018).

\subsubsection{Formative Assessment Components and Their Relationship with Motivation to Learn}

Formative assessment is thought to alter students' needs for autonomy, competence, and relatedness, and hence develop a kind of autonomous motivation (Leenknecht et al., 2021). In this study we have chosen to treat formative assessment components and their impact on student motivation based on the model offered by Brookhart et al. (2009). Table 2 illustrates the relationship between formative assessment components and motivation components.

\section{METHODOLOGY}

\subsection{Research Design}

To study assessment practices and their effects on students' motivation in English and to answer the research questions, a non-experimental, correlation study was undertaken. Creswell had stated," A research correlation design is useful to describe the relationship between two or more variables, to predict the results of a variable from the variable results of the other participants" (Creswell, 2008).

The methodology used in this study aimed to achieve the research objectives; it combined primary data with secondary ones. Secondary data are the result of literature review and contemporary literature related to assessment practices. This literature was obtained from various electronic searches, similar studies of neighboring countries and the region, as well as from a variety of other sources that have served to complement the theoretical part of this study. 
Table 2. Relationship between formative assessment components and motivation components.

\begin{tabular}{|c|c|c|}
\hline $\begin{array}{l}\text { Formative } \\
\text { Elements ... }\end{array}$ & $\begin{array}{l}\text {.. Help Students Harness the Workings of } \\
\text { Their Own Minds in the Following Ways } \\
\text {... }\end{array}$ & $\begin{array}{l}\text {... to Generate Components of } \\
\text { Motivation to Learn }\end{array}$ \\
\hline \multirow{3}{*}{$\begin{array}{l}\text { Shared Learning Targets and } \\
\text { Criteria for Success }\end{array}$} & $\begin{array}{l}\text { Directs students and teachers toward } \\
\text { specific goals. }\end{array}$ & \multirow{19}{*}{$\begin{array}{ll}\text { - } & \text { Self-efficacy } \\
\text { - } & \text { Self-assessment } \\
\text { - } & \text { Self-regulation } \\
\text { - } & \text { Self-attribution }\end{array}$} \\
\hline & - $\quad$ Increases initiation for the learning task. & \\
\hline & $\begin{array}{l}\text { - Helps students and teachers monitor } \\
\text { learning progress. }\end{array}$ & \\
\hline \multirow{3}{*}{ Feedback } & $\begin{array}{l}\text { Enhances the ability to process } \\
\text { information in the brain. }\end{array}$ & \\
\hline & $\begin{array}{l}\text { Encourages resilience and perseverance in } \\
\text { the face of challenge. }\end{array}$ & \\
\hline & $\begin{array}{l}\text { - Students are given clear next-step } \\
\text { strategies. }\end{array}$ & \\
\hline \multirow{3}{*}{ Student Goal Setting } & - $\quad$ Increases active student participation. & \\
\hline & $\begin{array}{l}\text { - Students' attention is shifted from } \\
\text { performance to goal-directed behavior. }\end{array}$ & \\
\hline & $\begin{array}{l}\text { - Encourages effort, perseverance, and the } \\
\text { invention of new techniques. }\end{array}$ & \\
\hline \multirow{3}{*}{ Student Self-Assessment } & $\begin{array}{l}\text { Power is transferred from the teacher to } \\
\text { the student. }\end{array}$ & \\
\hline & $\begin{array}{l}\text { - Students are actively gathering and } \\
\text { assessing assessment data in this activity. }\end{array}$ & \\
\hline & $\begin{array}{l}\text { - Assists students in setting more realistic } \\
\text { and active goals to maintain a high level of } \\
\text { achievement. }\end{array}$ & \\
\hline \multirow{3}{*}{ Strategic Teacher Questioning } & $\begin{array}{l}\text { - Students and teachers are directed to } \\
\text { important aspects of the subject, process, or } \\
\text { performance. }\end{array}$ & \\
\hline & $\begin{array}{l}\text { - Learners' understandings are scaffolded as } \\
\text { they go beyond incomplete, thin, or inactive } \\
\text { understandings. }\end{array}$ & \\
\hline & - $\quad$ Encourages the development of new ideas. & \\
\hline \multirow{4}{*}{$\begin{array}{l}\text { Engagement of Students in } \\
\text { Asking Effective Questions }\end{array}$} & $\begin{array}{l}\text { Increases students' intentional and active } \\
\text { participation. }\end{array}$ & \\
\hline & Promotes self-sufficiency and autonomy. & \\
\hline & $\begin{array}{l}\text { Students' ideas of themselves as knowledge } \\
\text { makers and creators of key subjects of inquiry } \\
\text { are shaped. }\end{array}$ & \\
\hline & $\begin{array}{l}\text { Gives students the confidence to solve } \\
\text { problems on their own. }\end{array}$ & \\
\hline
\end{tabular}

Source: Moss and Brookhart (2009).

\subsubsection{Data Collection}

To achieve the research objectives, to take students' opinion on the effects of assessment practices on student motivation in learning a second language, a survey was also conducted to collect data. The survey aimed to find out about the attitudes, opinions, behaviors, or characteristics of the sample examined. As a part of the survey, a questionnaire was administered in 3 main high schools in, Durres, Albania aiming to provide a more comprehensive representation of students.

\subsubsection{Instrument Factorial Analyses}

The statistical analysis was obtained from students' questionnaire in the form of factor analysis, which analyzed in detail the key factors that influenced motivation and proceeded further with multiple linear regression equation. 
Referring to questionnaire information and achieving the aim of this study, its elements were grouped into independent and dependent variables.

The independent variables related to assessment practices were:

- Students' portfolio (measured with 9 questions).

- Self-assessment (measured with 8 questions).

- Peer assessment (measured with 8 questions).

- Teachers' strategic questioning (measured with 6 questions).

The dependent variables related to motivation were:

- Goal orientation (measured with 4 questions).

- $\quad$ Interest (measured with 6 questions).

- $\quad$ Sense of self as a learner (measured with 4 questions).

- $\quad$ Effort (measured with 4 questions).

- $\quad$ Self-esteem (measured with 4 questions).

- Self-regulation (measured 4 questions).

- $\quad$ Self-efficacy (measured with 5 questions).

- Locus of control (measured with 4 questions).

The following conceptual model (Figure 1) was drawn to illustrate the analysis structure:

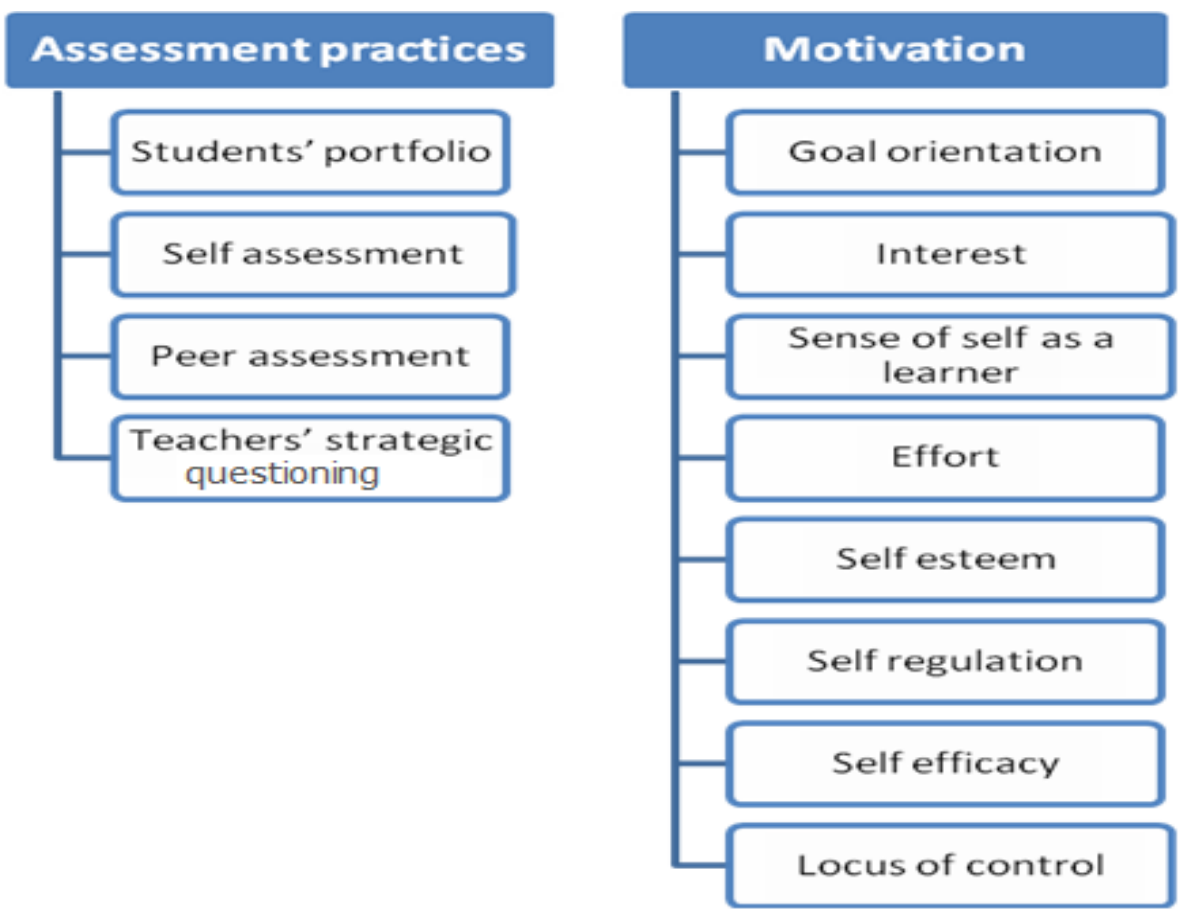

Figure 1. Assessment practices and motivation conceptual model showing IVs and DVs.

Independent variables were measured with 31 questions, while the dependent variables were measured with 35 questions. Each of the sets of variables were examined by calculating the Cronbach Alpha reliability coefficient, which for the independent variables was $0.871>0.7$ (the limit) showing that a high credibility of all questions while the reliability coefficient for the dependent variables was 0.888. If we see the Cronbach Alpha coefficient and weights of each of independent variables, it is seen that limit weight, which allows factors to continue further analysis, was 0.4. The first independent variable, student's portfolio was measured with nine questions. Factorial 
Analysis of their weight indicated that, excluding the fourth question, all the other questions could continue further analysis, and the Cronbach Alpha coefficient questions was 0.781

The study made use of 300 students, but the final database contained the responses of 278 of them (defined as the sample). The rest had no relevant information to be included in the study. Data collection lasted about 3 months (January to March 2021). At first, the participants were introduced with the research objectives. All participants were assured that the data, which would emerge from the report, would be only the object of study and remain completely anonymous. They were also asked to voluntarily complete the questionnaire. The completion of the questionnaire by the participants lasted 20 -30 minutes. Each participant completed the questionnaire individually, not influenced by external factors. At the end, the participants were thanked for their contribution.

\section{FINDINGS}

\subsection{Students' Perceptions about the Use of Portfolio as an Assessment Practice in Learning English}

In order to get information about students' perceptions about the use of portfolio as a means of assessment, they were asked whether portfolio assessment was used: - Do your teachers use portfolios as an assessment practice? $65.7 \%$ of students responded positively out of which a majority had come from public schools (87.1\%). The remaining number of students (34.3\%) responded that teachers did not use student portfolios, $75.6 \%$ of whom had come from public schools and the rest $24.4 \%$ from non-public schools (Figure 2).

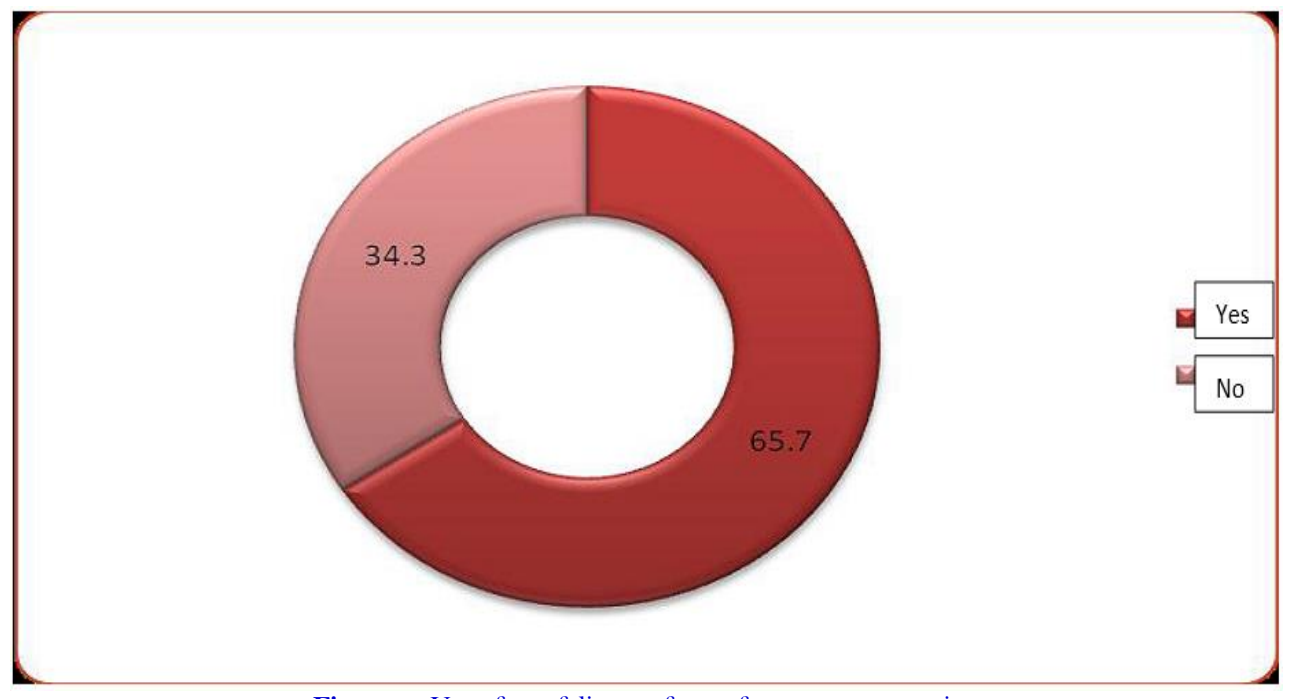

Figure 2. Use of portfolio as a form of assessment practice.

Students who responded positively in relation to the use of students' portfolio as an assessment practice were continually asked about their perceptions about its use as an effective assessment practice. Table 3 clearly shows that higher values related to agreement (agree or strongly agree) goes for the statement - I like to use portfolio for my assessment, with $65.7 \%$, followed by - Teachers' instructions about portfolio completion have helped me recognize my strengths and weaknesses- with $63.1 \%$ and $58 \%$ for the statement - When I complete the portfolio, I think about the result. All these three statements are closely related to students' portfolio as an assessment practice. They are followed by other statements - Students' portfolio as an assessment practice has changed my way of thinking, when I face problems -with $53.3 \%$, Portfolio has helped me become independent- with 52\%, -During portfolio completion, I think about the task- with $50.6 \%$. The statements with the lowest value of the responses (agree or strongly agree) were respectively $27.7 \%$ and $24.5 \%$ for Completing the portfolio is a difficult process for me-and-The teacher does not give us enough guidance materials (tasks) that we need. Other values were shared between responses 'disagree' and 'strongly disagree', while the neutral responses ranged between $10 \%-24 \%$ of the responses. 
Table 3. Descriptive statistics about students' portfolio.

\begin{tabular}{l|c|c|c|c|c|c}
\hline Alternatives & $\begin{array}{l}\text { Strongly } \\
\text { disagree }\end{array}$ & Disagree & Neutral & Agree & $\begin{array}{c}\text { Strongly } \\
\text { agree }\end{array}$ & Total \\
\hline $\begin{array}{l}\text { I like to use my portfolio as an } \\
\text { assessment practice }\end{array}$ & 10.1 & 13.4 & 10.8 & 30.3 & 35.4 & 100.0 \\
\hline $\begin{array}{l}\text { Portfolio has helped me become } \\
\text { independent }\end{array}$ & 12.0 & 14.4 & 21.6 & 32.2 & 19.8 & 100.0 \\
\hline $\begin{array}{l}\text { Portfolio completion is a difficult process } \\
\text { for me. }\end{array}$ & 29.2 & 19.1 & 24.1 & 17.4 & 10.2 & 100.0 \\
\hline $\begin{array}{l}\text { During portfolio completion, I think } \\
\text { about the task. }\end{array}$ & 13.3 & 15.9 & 20.2 & 32.1 & 18.5 & 100.0 \\
\hline $\begin{array}{l}\text { The teacher does not give us enough } \\
\text { guidance materials (tasks) required to } \\
\text { complete the portfolio. }\end{array}$ & 46.5 & 13.1 & 15.9 & 15.1 & 9.4 & 100.0 \\
\hline $\begin{array}{l}\text { When I complete the portfolio, I think } \\
\text { about the result. }\end{array}$ & 7.3 & 15.6 & 19.1 & 33.7 & 24.2 & 100.0 \\
\hline $\begin{array}{l}\text { Students portfolio as an assessment } \\
\text { practice has changed my way of thinking } \\
\text { when I face problems. }\end{array}$ & 9.7 & 14.1 & 23.0 & 31.8 & 21.4 & 100.0 \\
\hline $\begin{array}{l}\text { Portfolio has changed my attitude toward } \\
\text { learning }\end{array}$ & 11.8 & 14.8 & 23.1 & 29.2 & 21.2 & 100.0 \\
\hline $\begin{array}{l}\text { Teacher instructions in completing } \\
\text { portfolio have helped me recognize my } \\
\text { strengthens and weakness }\end{array}$ & 9.4 & 11.2 & 16.3 & 29.6 & 33.5 & 100.0 \\
\hline
\end{tabular}

\subsection{Students' Perceptions about the Use of Self-Assessment as an Assessment Practice in Learning English}

With regard to students' perceptions about self-assessment as a means of assessment, the students were asked: - Does your teacher create opportunities for self-assessment? $81.5 \%$ responded positively that they had opportunities to self-assess in the classroom, while the rest $18.5 \%$ felt that they did not have these opportunities (Figure 3).

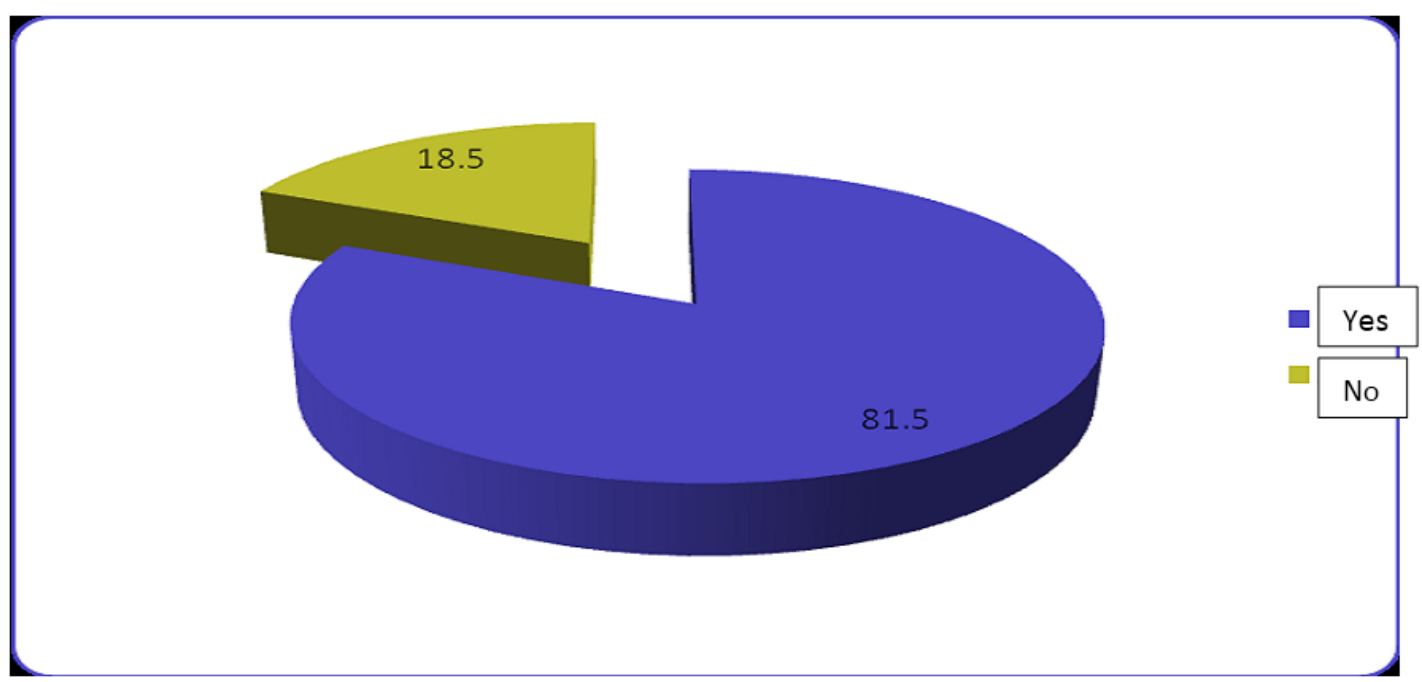

Figure 3. The use of Self-assessment as an assessment practice.

Students' perceptions about self-assessment are presented in Table 4. The table shows that statements related to agree or strongly agree - I can understand my strong and weak sides- scored $83.2 \%$ followed by - I feel involved in the learning process -with $77.5 \%$. These findings suggest that self-assessment relate to both positive achievements and shortcomings. Statements like - I try to understand and use the assessment criteria- and -I gain confidence in my abilities respectively- were rated with $74.7 \%$ and $74.2 \%$, while the other statements ranged between $69.7 \%$ to $73.6 \%$. The statement which had the lowest value of only $32.1 \%$ was: - I feel confused in this subject- which also was valued $30.4 \%$ for 'strongly disagree', the rest were neutral or disagreed with the fact. 
Table 4. Descriptive statistics about self- assessment as an assessment practice.

\begin{tabular}{|c|c|c|c|c|c|c|}
\hline Alternatives & $\begin{array}{l}\text { Strongly } \\
\text { disagree }\end{array}$ & Disagree & Neutral & Agree & $\begin{array}{l}\text { Strongly } \\
\text { agree }\end{array}$ & Total \\
\hline $\begin{array}{l}\text { I try to understand and use assessment } \\
\text { criteria. }\end{array}$ & 4.5 & 9.5 & 11.4 & 42.3 & 32.4 & 100.0 \\
\hline $\begin{array}{l}\text { I accurately determine what to improve in } \\
\text { terms of mastery skills or concepts. }\end{array}$ & 1.7 & 10.1 & 16.4 & 38.7 & 33.1 & 100.0 \\
\hline $\begin{array}{l}\text { Identify strategies that will improve my } \\
\text { understanding and abilities in this subject }\end{array}$ & 2.1 & 8.2 & 16.1 & 40.9 & 32.7 & 100.0 \\
\hline $\begin{array}{l}\text { I can understand my strong and weak } \\
\text { sides }\end{array}$ & 2.6 & 4.6 & 9.7 & 35.5 & 47.7 & 100.0 \\
\hline I feel independent in my job. & 3.5 & 10.4 & 16.5 & 34.2 & 35.5 & 100.0 \\
\hline I feel involved in the learning process. & 3.1 & 6.9 & 12.5 & 36.2 & 41.2 & 100.0 \\
\hline I feel confused about my performance & 30.4 & 18.3 & 19.2 & 18.4 & 13.7 & 100.0 \\
\hline I gain confidence in my abilities. & 5.1 & 9.5 & 11.1 & 32.8 & 41.5 & 100.0 \\
\hline
\end{tabular}

4.3. Students' Perceptions about the Use of Peer Assessment as an Assessment Practice in Learning English

$78.4 \%$ of students answered "Yes" to the question -Does your teacher create opportunities for peer assessment in this subject? while $21.6 \%$ answered it negatively (Figure 4 ).

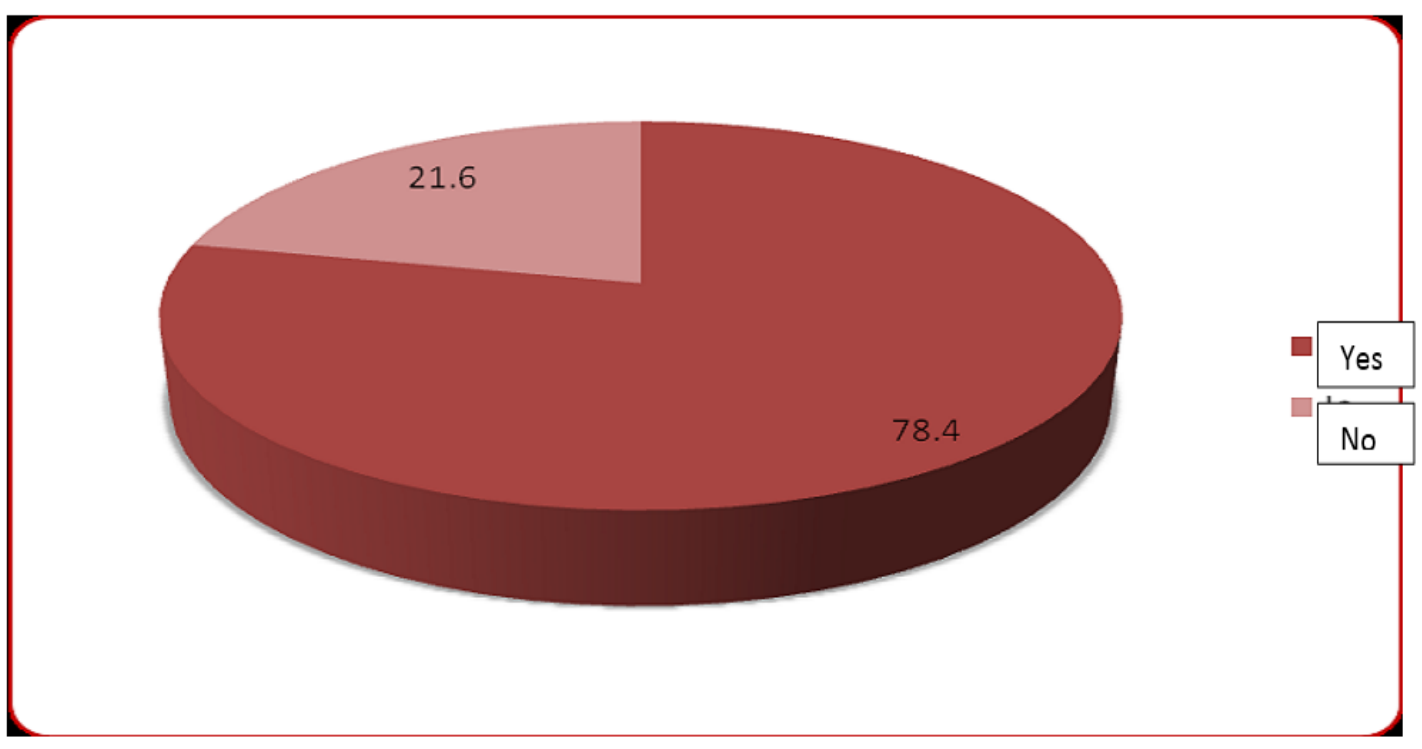

Figure 4. The use of Peer assessment as an assessment practice

Students who responded positively about peer assessment opportunities were further asked about their perception. The value for 'Agree' and 'Strongly agree' for the statement - I gain confidence in my abilities was $72.5 \%$ while for First, I understand and then use the assessment criteria- it was $70.2 \%$. Statements like - I clarify myself and my peer at the same time. - I analyze myself and my peer, at the same time. - and-I assess myself and my peer at the same time. received respectively $69.5 \%, 63.9 \%$ and $66.7 \%$. - I get feedback from my peer who assess my work- with $61.3 \%$ while the other statements - I like that classmate correct my work. - and- Peer assessment makes me feel frustrated. - have lower values respectively with $46.5 \%$ and $20.8 \%$ (see Table 5 ).

\subsection{Students' Perceptions about the use of Strategic Questions of Teachers as an Assessment Practice in Learning English}

To study students' perceptions about strategic questions of teachers as an assessment practice, first students were asked about what kind of questions teachers used to assess them. They responded that $77.8 \%$ of questions were explanatory, while $22.2 \%$ of them were reproductive questions (Figure 5). 
Table 5. Descriptive statistics about peer assessment.

\begin{tabular}{l|c|c|c|c|c|c}
\hline Alternatives & $\begin{array}{l}\text { Strongly } \\
\text { disagree }\end{array}$ & Disagree & Neutral & Agree & $\begin{array}{c}\text { Strongly } \\
\text { agree }\end{array}$ & Total \\
\hline I clarify what I do not understand & 9.4 & 8.8 & 12.3 & 39.7 & 29.8 & 100.0 \\
\hline $\begin{array}{l}\text { I analyze myself and my peer at the } \\
\text { same time. }\end{array}$ & 7.5 & 13.6 & 15.0 & 37.9 & 26.0 & 100.0 \\
\hline $\begin{array}{l}\text { I receive feedback from the peer who } \\
\text { corrects my work }\end{array}$ & 7.1 & 11.8 & 19.8 & 36.4 & 24.8 & 100.0 \\
\hline $\begin{array}{l}\text { I assess myself and my peer at the same } \\
\text { time, }\end{array}$ & 5.8 & 9.3 & 18.2 & 36.3 & 30.4 & 100.0 \\
\hline $\begin{array}{l}\text { First, I understand assessment criteria } \\
\text { I gain confidence in my abilities }\end{array}$ & 3.4 & 11.3 & 15.2 & 39.1 & 31.1 & 100.0 \\
\hline $\begin{array}{l}\text { Assessing my peer makes me feel a } \\
\text { failure. }\end{array}$ & 49.5 & 14.4 & 15.3 & 11.3 & 9.5 & 100.0 \\
\hline I like that my peer corrects my work. & 17.4 & 18.6 & 17.5 & 23.0 & 23.5 & 100.0 \\
\hline
\end{tabular}

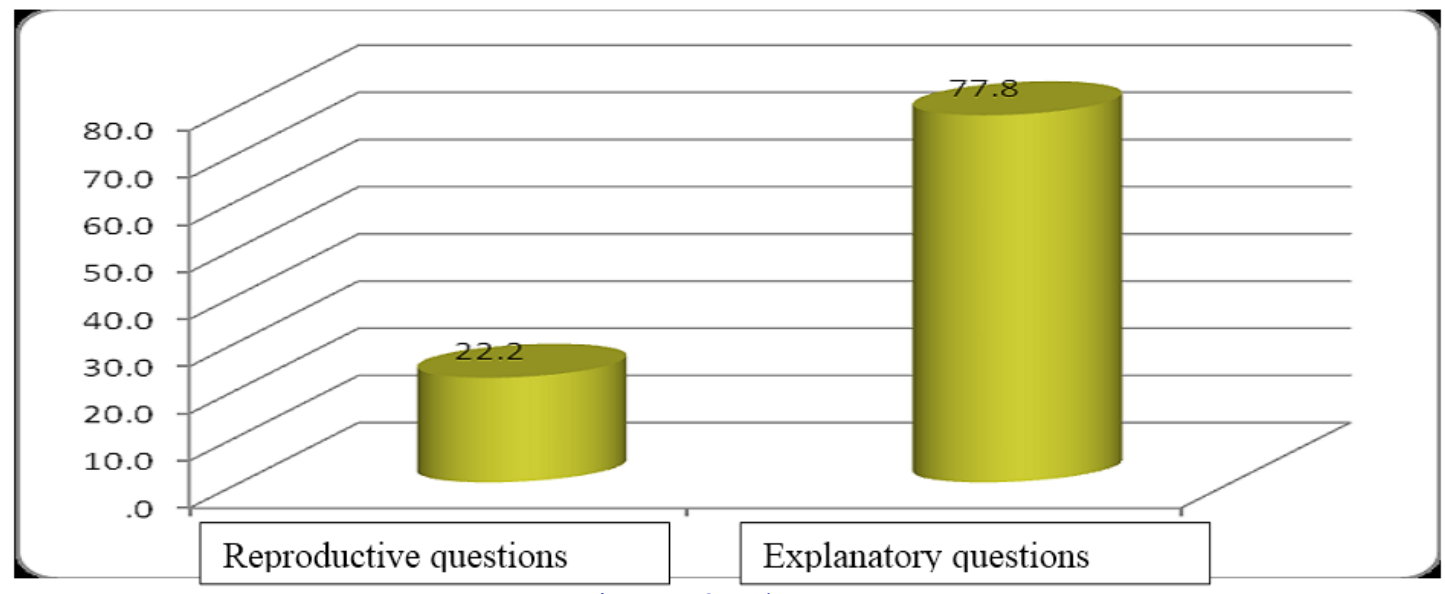

Figure 5. Question types.

Strategic questions were not only important due to their form, but also for its content. Students were asked Are teachers' questions related to the subject content? - More than half (53.2\%) reported that the questions were always related to the subject content, while $29.2 \%$ stated that they were often related to subject content. The rest of responses were divided between occasionally (8.9\%), sometimes (6.3\%), and never (2.5\%)(Figure 6).

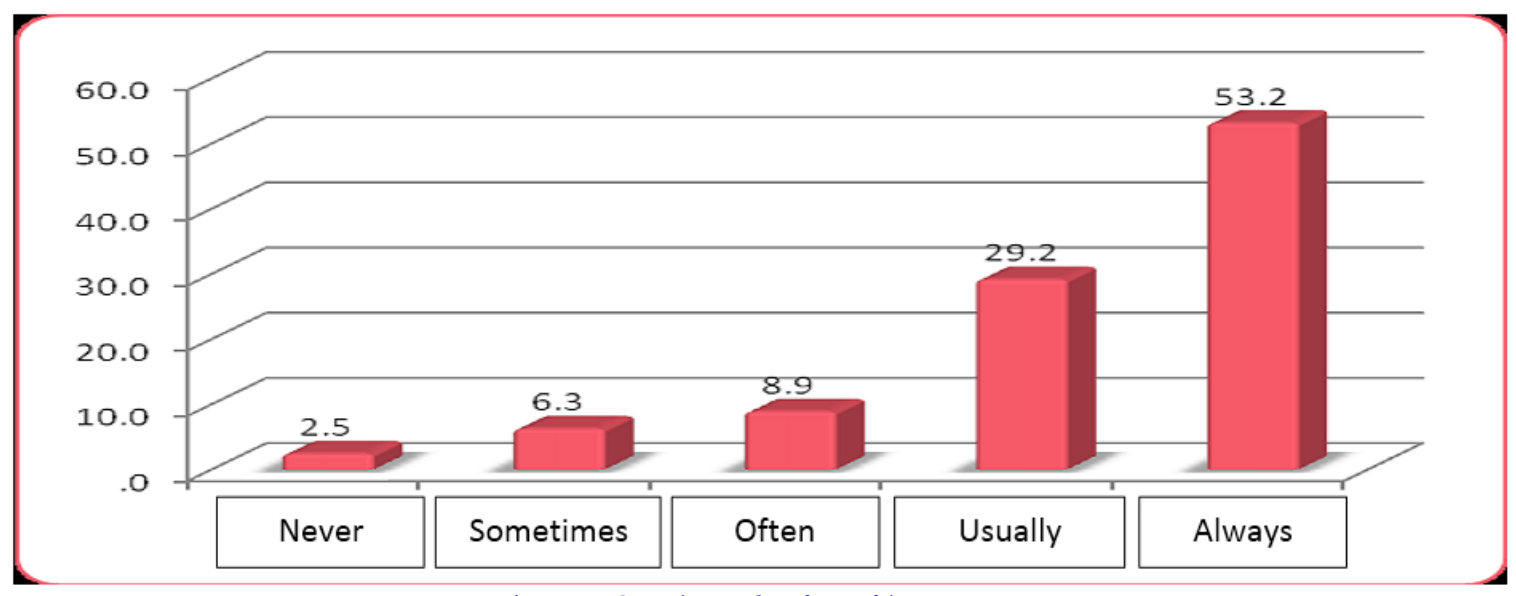

Figure 6. Questions related to subject content.

Students were also asked questions like if- Teacher's questions stimulate debates and comments; -Teacher asks in relation to learning targets; - I understand where I should improve etc. 
According to Table 6, 80.5\% responded positively to - I understand where I should improve- Many of them agreed with the fact that: - They reflect about their knowledge and skills- with 73.8\%. 71.2\% of them agreed to-Assessment makes them understand their strong and weak sides. - About 3/4 of them also stated that- Teacher questions are consistent with learning targets. - while $10.1 \%$ partially agreed and only 30 students, or $2.7 \%$ of the total number disagreed. $47.1 \%$ claimed that- Teacher's questions stimulate debates and comments. - It was a positive fact that -Teachers respect the waiting time for students' response. - for $65.9 \%$ of student The rest of the respondents were neutral, disagreed or partially agreed.

Table 6. Descriptive statistics about teachers' questions strategies.

\begin{tabular}{l|c|c|c|c|c|c}
\hline Alternatives & $\begin{array}{l}\text { Strongly } \\
\text { disagree }\end{array}$ & Disagree & Neutral & Agree & $\begin{array}{c}\text { Strongly } \\
\text { agree }\end{array}$ & Total \\
\hline $\begin{array}{l}\text { Teacher's questions stimulate debates } \\
\text { and comments. }\end{array}$ & 15.4 & 21.3 & 16.3 & 28.7 & 18.4 & 100.0 \\
\hline $\begin{array}{l}\text { Teacher asks in relation to learning } \\
\text { targets. }\end{array}$ & 2.7 & 10.1 & 12.7 & 39.2 & 35.3 & 100.0 \\
\hline I understand my strong and weak sides. & 3.9 & 8.5 & 16.4 & 35.0 & 36.2 & 100.0 \\
\hline $\begin{array}{l}\text { Teachers respect the waiting time for } \\
\text { students' responses. }\end{array}$ & 6.8 & 12.8 & 14.5 & 32.5 & 33.5 & 100.0 \\
\hline I reflect about my knowledge and skills. & 3.9 & 8.5 & 13.7 & 39.6 & 34.2 & 100.0 \\
\hline
\end{tabular}

4.5. The Relationship between Formative Assessment Practices (Portfolio, Self-Assessment, Peer Assessment, and Teachers' Strategic Questions) and Motivation for Learning English, and Which are the Formative Assessment Practices with Greater Impact on Student Motivation for Learning.

H: There is a positive relationship between formative assessment practices (students' portfolio, self-assessment, peer assessment, and teachers' strategic questions) and students' motivation for learning English.

To determine this relationship and to test the hypothesis, we used a linear regression analysis. Each of the elements of independent variables of assessment practices and the elements of dependent variables of motivation were measured with the average of their questions. The linear regression equation had the following form:

$($ Motivation $)=1.606+0.042($ students' portfolio $)+0158($ Self-assessment $)+0138($ Peer assessment $)+0207$ (teachers' strategic questions)

As shown in the regression equation, all the independent variables influenced motivation because they were statistically significant, but one that has the greatest impact was teachers' strategic questions $(\beta 4=0.207)$, followed by self-assessment $\left(\beta_{3}=0158\right)$, peer assessment $\left(\beta_{2}=0.138\right)$ and at the end students' portfolio $\left(\beta_{1}=0.042\right)$. This explained the changing values $(25.8 \%)$ for motivation variables (Table 7 ). All the coefficients of the regression equation were positive which meant the growth of each independent factor influenced an increase in the dependent variable.

Table 7. Multiple regression analysis between independent variables and the average of dependent motivation variable.

\begin{tabular}{l|c|c|c|c}
\hline Model & R2 & Adjusted R2 & t & Sig. \\
\hline Constant & 0.262 & 0.258 & & 0.000 \\
\hline Students' portfolio & & & 3.223 & 0.001 \\
\hline Self-assessment & & & 4.719 & 0.000 \\
\hline Peer assessment & & & 4.824 & 0.000 \\
\hline Teachers' strategic questions & & & 8.223 & 0.000 \\
\hline
\end{tabular}

\section{DISCUSSION}

5.1. Students' Perceptions about the Use of Portfolio as an Assessment Practice in Learning English

To identify students' perceptions about formative assessment practices this quantitative study found out that $65.7 \%$ of students stated that they used student's portfolio as an assessment practice, out of which $87.1 \%$. belonged 
to public schools. Students' perception about the portfolio assessment showed that they preferred portfolio as selfassessment method. Teacher's instructions about portfolio usage helped them to understand their weak and strong points. During the portfolio completion, students could think about the final assessment. Students also claimed that portfolio assessment had changed their way of thinking in affronting problems, whereas the portfolio itself helped them become independent. During the portfolio completion, students also always thought about the task completion.

Findings about students' perception of using portfolio as an assessment practice pointed out that portfolio helped students become autonomous, develop prompt critical thinking, and grades improvement. Similar conclusions are found in Harris, Dolan, and Fairbairn (2001) who affirmed that using portfolio encouraged students. Belanoff (1994) also affirmed that portfolio as an assessment practice prompted students' independence and promoted their engagement and autonomy. Portfolio helped them to reflect on their work, to choose the work they wanted to be assessed, it also helped them to redefine their work and improve it, to take challenge in writing process and ask advice from their friends. As we can see assessment is a positive factor, it prompted students' improvement, maturity, and independence and did not prove to be a tool to show their weakness (Belanoff, 1994).

\subsection{Students' Perceptions about the Use of Self-Assessment as an Assessment Practice in Learning English}

Quantitative data analysis found out that self-assessment helped student in understanding his/her strong and weak points. During assessment, they felt engaged in the learning process, and this was very important because it emphasized their positive achievements and gaps as well.

Our findings are same as consistent with other empirical studies, like (Blue, 1994; Dickinson, 1987; Harris, 1997; Oscarson, 1989). These scholars argued that assessment was important for students' autonomy and that teachers should create opportunities for students to assess their linguistic level and help them to achieve it. Hunt, Gow, and Barnes (1989) believed that without self-assessment, there could not be real autonomy for students (Hunt et al., 1989).

The finding that assessment prompts students learning is in line with Sadler and Good (2006), who took a study where students were trained to use their work assessment rubrics and the results showed that students who had assessed their work improved in their second assessment.

\subsection{Students' Perceptions about the use of Peer-Assessment as an Assessment Practice in Learning English}

Quantitative data analysis showed that peer assessment helped students to gain trust in their skills. Peer assessment helped also in understanding what they had not understood because students analyzed themselves and their friends at the same time.

Empirical studies have shown that this assessment practice prompts a high-level thinking, helping in developing student centered methodologies. It encourages active and flexible learning and develops a deep approach to it. Students gain from peer assessment, according to a recent meta-analysis by Li, Xiong, Hunter, Guo, and Tywoniw (2020) especially when it is accompanied by peer assessment training. After conducting meta-analyses on the impact of self-assessment on self-regulated learning and students' self-efficacy, Panadero, Jonsson, and Botella (2017) has found that "self-assessment is a necessity for productive learning"

\subsection{Students' Perceptions about the use of Teachers' Strategic Questions as an Assessment Practice in Learning English}

With regard to teachers' strategic questions, students were first asked about compatibility of learning targets with teachers' strategic questions and if they understood how and where they would improve. Students stated that teachers 'strategic questions made them understand their strong and weak points. Such findings are consistent with Clarke (2005) \& Cazden (2001). 
In conclusion, we may say that strategic questions made by teachers affect positively students' achievements. Teacher questions remain the most common way of interaction between teacher and student. Qualitative questions, as Clarke (2005) affirms, can result in fast and positive changes in the class which have a strong effect on students. This is in line with Cazden (2001), who also stated that during formative assessment, strategic questions could help and assess learning (Cazden, 2001).

5.5. The Relationship between Formative Assessment Practices (Portfolio, Self-Assessment, Peer Assessment, and Teachers' Strategic Questions) and Motivation for Learning English, and Which are the Formative Assessment Practices with Greater Impact on Students' Motivation for Learning

The hypothesis raised in this study was confirmed by the equation of multiple linear regression and showed, as expected, a positive and significant statistical relationship between independent variables (students' portfolio, selfassessment, peer assessment, and strategic questioning) and motivation for learning). The result of the regression equation also found that all the independent variables had an impact on motivation, but the factor with the greatest impact was, strategies that the teacher used in evaluating oral learning $(\beta 4=0207)$, followed by Self-assessment $(\beta 3=0,158)$ peer assessment $(\beta 2=0.138)$ and finally students' portfolio $(\beta 1=0.042)$, in total explaining $25.8 \%$ of the changing values of the variables of motivation. Similar results were found by Brookhart et al. (2009) on the topic of evaluation practices and the influence of motivation and mastery of learning from students.

This study revealed the findings of a study for five years and was based on formative assessment, communication teacher-student and ownership of learning from students, indicating that the assessment formative is closely linked with the promotion of intrinsic motivation of students, and it helps them to exploit their capabilities, to create and strengthen steadily four important components of motivation to learn:

- Self-efficacy: student confidence in their ability to succeed in a particular situation.

- Self-regulation: faulty recognition, as active participants in the learning process.

- Self-assessment: Students analyze and judge their performance based on criteria and determine how they can improve it.

- Self-attribute: perceptions of students or explanations about success or failure, which determine the amount of effort in the future.

\section{CONCLUSION}

The aim of this study was to explore and provide a comprehensive overview of formative assessment practices and their impact on students' motivation or learning English as a foreign language.

This study was based on formative assessment, communication teacher-student and ownership of learning from students, indicating that the assessment formative is closely linked with the promotion of intrinsic motivation of students, and it helps them to exploit their capabilities, to create and strengthen steadily four important components of motivation to learn:

- Self-efficacy: student confidence in their ability to succeed in a particular situation.

- Self-regulation: faulty recognition, as active participants in the learning process.

- Self-assessment: Students analyze and judge their performance based on criteria and determine how they can improve it.

- Self-attribute: perceptions of students or explanations about success or failure, which determine the amount of effort in the future.

This study found out that by using portfolio as an assessment practice, it changed students' way of thinking, particularly when they faced various problems during the learning process. It also developed their critical thinking through reflection. Thus, assessment practices made a positive impact on students' autonomy helping them to be independent. As a result, the portfolio was found to be a motivational assessment practice, which promoted 
autonomy and independence. Portfolio was an efficient assessment practice because it promoted improvement, maturity, and independence and it was not just a tool to expose the shortcomings of students. Portfolio helped them to be critical thinkers and independent consequently motivating them in learning English as a foreign language.

Self-assessment was also found making a positive impact on student motivation for learning as it affected students' cognition, helping them realize their strengths and weaknesses. Self-assessment involved students in assessment by shifting the focus of assessment from teachers to students. During the self-assessment, students selfassess their linguistic level focusing on improvement, not only in assessment. The study also found that peer assessment promoted critical thinking, reflection, and self-analysis. This assessment practice helped students to gain confidence in their abilities, giving them the sense of independence. It also encouraged active learning, and it was a flexible and meaningful approach, rather than a surface approach to learning. Consequently, peer assessment also was seen making a positive impact on student motivation for learning English as a foreign language.

Finally, it was found that teachers' strategic questions encouraged debate and comments, as they were the most common form of teacher-student's interaction, helping students understand what they needed to improve. This formative assessment proactive impacted positively the student achievement and launched analytical and critical thinking, helping them to reflect on their performance. This study also highlighted some recommendations for the English teachers as follow;

- To promote and use more student portfolio, as the findings of this study have shown that it is used rarely as an assessment practice.

- To engage students in assessment practices such a self-assessment and peer assessement.

- To share assessment criteria with students both in written tests and through projects.

- To use formative assessessment practices that boost student motivation, such as: teacher strategic questions, student portfolio, self-assessment and peer assessment.

- $\quad$ To give descriptive and explanatory feedback immediately after the assessement.

This study has also its limitations such as the influence of school premises on students answers due to the fact that student questionnaires were conducted in the classroom may have influenced their answers or the provision of "desirable" answers. Another limitation is the lack of studies on some of the research objectives, which makes impossible comparing and contrasting findings.

Funding: This study received no specific financial support.

Competing Interests: The authors declare that they have no competing interests.

Acknowledgement: Both authors contributed equally to the conception and design of the study.

\section{REFERENCES}

Belanoff, J. (1994). How a teacher's beliefs and knowledge inform practice. Paper presented at the Annual Meeting of the National Association for Research in Science Teaching. Atlanta, Georgia.

Black, P., \& Wiliam, D. (2009). Developing the theory of formative assessment. Educational Assessment, Evaluation and Accountability (formerly: Journal of Personnel Evaluation in Education), 21(1), 5-31.

Black., P., \& Wiliam, D. (1998b). Inside the black box: Raising standards through classroom assessment. Phi Delta Kappan, 80(2), 139-148.

Black, P., Harrison, C., Lee, C., Marshall, B., \& Wiliam, D. (2004). Working inside the black box: Assessment for learning in the classroom. Phi Delta Kappan, 86(1), 8-21. Available at: https://doi.org/10.1177/003172170408600105.

Bloom, B. S. (1969). Some theoretical issues relating to educational evaluation. In R. W. Tyler (Ed.), Educational evaluation: new roles, new means: the 68th yearbook of the National Society for the Study of Education (part II) (Vol. 68, pp. 26-50). Chicago, IL: University of Chicago Press. 
Bloom, B. S., Hastings, J. T., \& Madaus, D. G. F. (1971). Handbook on formative and summative evaluation of student learning. New York: McGraw-Hill.

Bloom, B. S. (1984). The 2 sigma problem: The search for methods of group instruction as effective as one-to-one tutoring. Educational Researcher, 13(6), 4-16. Available at: https://doi.org/10.3102/0013189x013006004.

Blue, G. (1994). Self-assessment of foreign language skills: Does it work? (pp. 18-35). CLE Working Papers. No. 3.

Boud, D., Dawson, P., Bearman, M., Bennett, S., Joughin, G., \& Molloy, E. (2018). Reframing assessment research: Through a practice perspective. Studies in Higher Education, 43(7), 1107-1118. Available at: https://doi.org/10.1080/03075079.2016.1202913.

Brookhart, S., Moss, C., \& Long, B. (2009). Promoting student ownership of learning through high-impact formative assessment practices. Journal of MultiDisciplinary Evaluation, 6(12), 52-67.

Brookhart, S. M. (2011). Educational assessment knowledge and skills for teachers. Educational Measurement: Issues and Practice, $30(1), 3-12$.

Cazden, C. (2001). Classroom discourse: The language of teaching and learning. Portsmouth: NH: Heinemann.

Clarke, S. (2005). Formative assessment in the secondary classroom. London: Hodder Murray.

Council, A. (2006). Declaration. Paper presented at the Conference on the Cultural Dimension of the Cooperation among the Arctic Council Member States. Khanty-Mansiysk, January 18, 2006.

Creswell, J. (2008). Educational research: Planning, conducting, and evaluating quantitative and qualitative research. New Jersey: Pearson: Merrill Prentice Hall.

Davies, A. (2008). Leading the way to making classroom assessment work. Courtenay: Connections Publishing Inc.

Dickinson, L. (1987). Self-instruction in language learning. Cambridge: Cambridge University Press.

Dweck, C. (2001). Self-theories: Their role in motivation, personality and development. Philadelphia: Psychology Press.

Harris, M., Dolan, J., \& Fairbairn, J. (2001). From evidence to action: A seamless process in formative assessment? Educational Measurement. Issues and Practice, 28(3), 24-31.

Harris, M. (1997). Self-assessment of language learning in formal settings. ELT Journal, 51(1), 12-20. Available at: https://doi.org/10.1093/elt/51.1.12.

Hunt, J., Gow, L., \& Barnes, P. (1989). Learner self-evaluation and assessment - a tool for autonomy in the language learning classroom. In V. Bickley (Ed.), Language teaching and learning styles within and across cultures (pp. 207-2 17). Hong Kong: Institute of Language in Education.

Leahy, S., Lyon, C., Thompson, M., \& Wiliam, D. (2005). Classroom assessment minute by minute, day by day. Educational Leadership, 63(3), 14-28.

Leenknecht, M., Wijnia, L., Köhlen, M., Fryer, L., Rikers, R., \& Loyens, S. (2021). Formative assessment as practice: The role of students' motivation. Assessment $\Theta$ Evaluation in Higher Education, 46(2), 236-255. Available at: https://doi.org/10.1080/02602938.2020.1765228.

Lepper, M. R., Greene, D., \& Nisbett, R. E. (1973). Undermining children's intrinsic interest with extrinsic reward: A test of the'overjustification'hypothesis. Journal of Personality and Social Psychology, 28(1), 129-137. Available at: https://doi.org/10.1037/hoo35519.

Li, H., Xiong, Y., Hunter, C. V., Guo, X., \& Tywoniw, R. (2020). Does peer assessment promote student learning? A metaanalysis. Assessment \& Evaluation in Higher Education, 45(2), 193-211. Available at: https://doi.org/10.1080/02602938.2019.1620679.

Looney, J. (2011). Integrating formative and summative assessment: Progress toward a seamless system? OECD Education Working Papers, No. 58. OECD Publishing (NJ1).

Marzano, R. J. (2006). Classroom assessment and grading that work. Alexandria, VA: Association for Supervision and Curriculum Development.

Moss, C. M., \& Brookhart, S. M. (2009). Advancing formative assessment in every classroom: A guide for instructional leaders. Alexandria: VA: ASCD. 
O’Connor, K. (2009). Reforming grading practices in secondary schools. Principal's Research Review, 4(1), 1-7.

Oscarson, M. (1989). Self-assessment of language proficiency: Rationale and applications. Language Testing, 6(1), 1-13. Available at: https://doi.org/10.1177/026553228900600103.

Panadero, E., Jonsson, A., \& Botella, J. (2017). Effects of self-assessment on self-regulated learning and self-efficacy: Four metaanalyses. Educational Research Review, 22, 74-98. Available at: https://doi.org/10.1016/j.edurev.2017.08.004.

Popham, W. J. (2008). Transformative assessment. Alexandria, VA: ASCD.

Reeves, D. (2007). Ahead of the curve: The power of assessment to transform teaching and learning. Bloomington, IN: Solution Tree.

Sadler, D. R. (1983). Evaluation and the improvement of academic learning. The Journal of Higher Education, 54(1), 60-79. Available at: https://doi.org/10.2307/1981645.

Sadler, D. R. (1989). Formative assessment and the design of instructional systems. Instructional Science, 18(2), 119-144. Available at: https://doi.org/10.1007/bfoo 117714

Sadler, P. M., \& Good, E. (2006). The impact of self-and peer-grading on student learning. Educational Assessment, 11(1), 1-31. Available at: https://doi.org/10.1207/s15326977ea1101_1.

Scriven, M. (1967). The methodology of evaluation. In R. W. Tyler, R. M. Gagne, \&M. Scriven (Eds.), Perspectives of curriculumevaluation (pp. 39-83). Chicago: Rand McNally.

Stefanou, C. (2003). Effects of classroom assessment on student motivation in fifth-grade science. The Journal of Educational Research, 96(3), 152-162.

Stiggins, R. (2007). Assessment through students eyes. Educational Leadership, 64(8), 22-26.

William, D., \& Thompson, M. (2008). Integrating assessment with learning: What Will it take to make it Work? In C.A. DWyer (Ed.), The future of assessment: Shaping teaching and learning (pp. 53-82). New York: Lawrence Erlbaum Associates. 